\title{
A New Brand of Representational Standing
}

\author{
Tacy F. Flint $\dagger$
}

To have standing in a federal suit, a litigant must meet both constitutional and prudential requirements. Under the constitutional test, which arises from Article III's Case or Controversy Clause,' the plaintiff must establish a concrete injury in fact, causation between the alleged injury and the alleged conduct of the defendant, and redressability. ${ }^{2}$ To these constitutional requirements the Court has added prudential requirements: the plaintiff must assert her own particularized rights, and the plaintiff's complaint must fall "within the zone of interests to be protected or regulated by the statute or constitutional guarantee in question." ${ }^{3}$

The Court has established two narrow exceptions to this prudential doctrine. First, under associational standing, an association may bring suit on its members' behalf when the members would have standing in their own right, even if the association is not itself injured." Second, third-party standing allows a litigant to bring suit on behalf of a third party if the litigant and third party share a "close relationship," the litigant is also injured, and the third party is hindered from bringing the suit on her own behalf. ${ }^{5}$ Recently, a divided Third Circuit held that these two narrow exceptions may be combined to create a third exception to prudential standing doctrine called derivative standing." Derivative standing arises when an association pursues a claim that some or all of its members would have third-party standing to bring.

\footnotetext{
$\dagger$ A.B. 1999, Princeton University; J.D. Candidate 2004, The University of Chicago.

US Const Art III, § 2, cl 1.

See Lujan v Defenders of Wildlife, 504 US 555, 560-61 (1992).

Valley Forge Christian College v Americans United for Separation of Church and State, Inc, 454 US 464, 474-75 (1982) (quotation marks omitted).

4 See Hunt $v$ Washington State Apple Advertising Commission, 432 US 333, 342 (1977).

5 See Powers v Ohio, 499 US 400, 411 (1991).

6 See Pennsylvania Psychiatric Society v Green Spring Health Services, Inc, 280 F3d 278 (3d Cir 2002), cert denied, $123 \mathrm{~S} \mathrm{Ct} 102$ (2002) (upholding standing of a medical association to sue on behalf of its members' clients). A few other courts have implicitly permitted derivative standing without discussion. See Fraternal Order of Police v United States, 152 F3d 998, 1001-02 (DC Cir 1998) (allowing policemen's association to litigate on behalf of non-member police officers supervised by member chief law enforcement officers); Ohio Association of Independent Schools v Goff, 92 F3d 419, 421-22 (6th Cir 1996) (allowing association of independent schools to litigate on behalf of parents of students attending member schools); Public Citizen v FTC, 869 F2d 1541, 1550 (DC Cir 1989) (allowing public action group to sue on behalf of its members' children to require a federal agency to prohibit the sale of items advertising smokeless tobacco without a health warning).
} 
In other words, the association derives its claim from outside claims that its members would have third-party standing to pursue. The test for derivative standing thus entails two prongs: 1 ) the litigating association must show that it has associational standing on behalf of its members; and 2) the association must show that its members have third-party standing on behalf of some third-party right-holders.

The combination of associational and third-party standing, however, relies on an uncertain interpretation of past Supreme Court decisions. The Court has said that, to achieve associational standing, an association's members must have standing in their own right. The Court has not specified whether the members' standing must be firstparty (in other words, the members must have standing to assert claims on their own behalf) or whether it may be third-party (in other words, the members may assert claims on others' behalf). Choosing to allow associations to assert members' third-party claims means adopting a new brand of representational standing, one in which there are two steps of removal between the litigant and the right-holder rather than the one step permitted in associational and third-party standing individually.'

It is necessary to examine whether derivative standing involves a relationship too attenuated to meet jurisprudential requirements. Each additional step of removal raises concerns about the quality of the adversarial proceedings and due process. First, it is questionable whether an association litigating, not its members' claims but its members' third parties' claims, provides the "concrete adverseness" that standing doctrine seeks to ensure. Second, an association's selfinterested suit may negatively affect its members' third parties' claims without affording them adequate process. Finally, derivative standing may provide ideologically-minded associations with new, unfettered capacity to pursue the rights of diffuse, unwitting, and potentially unwilling third parties in Article III courts in order to achieve political goals better left to legislatures.

In this Comment, I argue that courts should uphold derivative standing. A thorough analysis of the theoretical underpinnings and policy objectives of the associational and third-party standing doctrines, which have enjoyed consistent support from the Court, reveals

7 In associational standing, the association has a direct relationship with its members on whose behalf it :s litigating. In third-party standing, the litigant has a direct relationship with the right-holder on whose behalf she is litigating. In derivative standing, the association has no direct relationship with the right-holder on whose behalf it is litigating; the association's relationship rests with its members, whose relationship in turn rests with the right-holder.

8 Baker v Carr, 369 US 186, 204 (1962).

9 See, for example, International Union, UAW v Brock, 477 US 274 (1986) (upholding associational standing); Powers, 499 US at 410-16 (upholding third-party standing). 
that their combination is both theoretically sound and a good policy decision. In Part I, I provide a more detailed explanation of derivative standing, as well as a discussion of the existing analysis. In Part II, I provide a background discussion of the standing doctrine and an explanation of the theoretical and policy rationales that have been offered in support of associational and third-party standing. In Part III, I argue that the restrictions that courts have applied to associational and third-party standing combine to ensure that derivative standing both preserves concrete adverseness and avoids due process problems. I also analyze the benefits of derivative standing and situate derivative standing in the ongoing scholarly debates over the role of standing in the separation of powers.

\section{Derivative STANDING}

\section{A. Derivative Standing Defined}

Derivative standing constitutes one more extension of the representative standing doctrine that allows litigants to bring the claims of non-parties, as in associational and third-party standing. In associational standing, an association brings its members' claims rather than the association's own claims; the association need not suffer injury in its own right. ${ }^{10}$ In third-party standing, a litigant brings the claims of a third party rather than her own; the litigant must also have suffered some injury, and the third party must be somehow hindered from bringing suit on her own behalf." Derivative standing results from combining these two well-recognized exceptions to the prudential limitations on standing, so that an association is permitted to bring claims for which its members would have third-party standing.

\section{Pennsylvania Psychiatric Society.}

In Pennsylvania Psychiatric Society v Green Spring Health Services, $I n c,{ }^{12}$ a divided Third Circuit allowed an association of psychiatrists to litigate on behalf of its members' clients, thereby authorizing the combination of the two exceptions to the standing doctrine. ${ }^{13}$ The case involved a suit brought by a psychiatrists' trade association, Pennsylvania Psychiatric Society (PPS), against various managed care organizations. PPS alleged that the health care groups improperly refused to authorize necessary treatment for the member psychiatrists' patients; PPS sought to sue on the patients' behalf in both tort and

\footnotetext{
See note 4 and accompanying text.

See note 5 and accompanying text.

280 F3d 278 (3d Cir 2002), cert denied, 123 S Ct 102 (2002).

See id at 291-93.
} 
contract. Confronted with the preliminary issue of whether PPS had standing, the Third Circuit first decided that the member psychiatrists would have third-party standing to litigate on behalf of their clients: The psychiatrists were themselves injured by the practice in question, they had the appropriate close relationship with their clients, and the stigma of mental illness constituted a sufficient hindrance to the clients representing themselves. ${ }^{14}$

Because the member psychiatrists thus would individually have standing (albeit third-party standing), the majority concluded that the first requirement of the test for associational standing - namely that the association's members have standing in their own right - was satisfied. ${ }^{\text {is }}$ The majority justified its analysis by explaining that " $[t]$ he Supreme Court did not delineate ... which types of claims associations could bring on behalf of their members, but rather simply held that 'an association has standing to bring suit on behalf of its members' when the requisite elements are established.," According to the Third Circuit, the only requisite element in question in Pennsylvania Psychiatric Society was whether the psychiatrists would otherwise have standing; since the court found that the psychiatrists' third-party standing was sufficient to satisfy this requirement, it held standing to be proper. This combination of associational and third-party standing effectively created a new doctrine. The court's holding, however, did not constitute a tremendous departure from previous standing decisions. Without explicitly recognizing derivative standing, many courts had implicitly accepted the concept prior to the Third Circuit's decision."

\section{Justifying Pennsylvania Psychiatric Society.}

The Third Circuit's decision makes sense on practical grounds: Had the court decided not to allow derivative standing, it would have functionally prevented the patients' claims from reaching litigation. The claim at issue was the patients' right under HMO contracts to authorization of psychiatric treatment. The court found that the patients were hindered from bringing their own claims because of the stigma

14 See id at 289-91. The Supreme Court has similarly held that doctors may bring thirdparty claims on behalf of their patients. See, for example, Singleton $v$ Wulff, 428 US 106, 118 (1976) (holding that "it generally is appropriate to allow a physician to assert the rights of women patients as against governmental interference with the abortion decision").

15 See Pennsylvania Psychiatric Society, 280 F3d at 291. The Third Circuit then remanded the case for determination of whether the other requirements of associational standing were satisfied. See id at 294.

16 Id at 291, quoting Hunt $v$ Washington State Apple Advertising Commission, 432 US 333, 343 (1977).

17 See note 6 . None of these courts expressed awareness that they were permitting a potentially controversial variety of standing. 
of mental illness. ${ }^{18}$ Thus, the patients would see their claims vindicated only if another party litigated their interests through representational standing. But no individual psychiatrist was likely to front the substantial resources required to litigate a patient's claim, ${ }^{19}$ even though the psychiatrists would also benefit by the enforcement of the patients' treatment authorization rights. Third-party standing alone, therefore, would not suffice to provide the patients access to the courts.

On the other hand, associational standing alone also could not bring about litigation of the patients' claims. PPS enjoyed the pooled resources of its member psychiatrists and could thus afford to litigate the patients' authorization rights. However, associational standing would allow PPS to litigate its member psychiatrists' claims, but not the patients' claims. Since the right to treatment authorization belonged to the patients and not the psychiatrists, PPS could not reach it through associational standing alone.

Derivative standing unites PPS's resources with the patients' colorable claims. Under derivative standing, PPS could derive standing from its member psychiatrists' third-party standing to bring the patients' claims. Instead of leaving the patients incapable of vindicating their alleged rights to treatment authorization, derivative standing helps both the patients and the psychiatrists by allowing the validity of those rights to be determined on the merits. Allowing derivative standing may well represent the only way such a case could go forward.

\section{B. Why Derivative Standing May Be Problematic}

\section{Separation of powers.}

Derivative standing may challenge one of standing's primary goals: to ensure that courts operate within the constitutionally appropriate bounds of the judicial branch's authority without compromising the principle of separation of powers. In a dissenting opinion in Pennsylvania Psychiatric Society, Judge Nygaard questioned whether derivative standing had a basis in the law:

PPS cannot piggy-back two discrete exceptions, to swallow up the long-standing rule that litigants must assert their own rights and interests. I cannot find, nor does PPS cite, any authority for stacking or piggy-backing these relationships into an attenuated con-

18 See Pennsylvania Psychiatric Society, 280 F3d at 290.

19 The psychiatrists' ability to bring third-party claims in their individual capacity was not a question before the Third Circuit. I am simply assuming that most psychiatrists would not individually pursue a claim on behalf of a patient absent extraordinary circumstances. 
catenation of exceptions to the standing rule so as to confer standing on PPS. ${ }^{20}$

Not explicitly mentioned-though clearly a present concern-in this dissent is the impact of derivative standing on separation of powers. The Supreme Court and then-Judge Scalia have touted the principle of standing as a necessary feature of the separation of powers. By limiting the opportunity to litigate to those who have actual "Cases" or "Controversies" under Article III, the standing doctrine effectively prevents courts from acting outside of their constitutional scope. "Absent the necessary allegations of demonstrable, particularized injury [as the standing test requires], there can be no confidence of 'a real need to exercise the power of judicial review' or that relief can be framed 'no broader than required by the precise facts to which the court's ruling would be applied." ${ }^{22}$ Since broad questions of policybetter suited to legislative determination-do not rise to the level of "Cases" or "Controversies," standing doctrine keeps them out of the courts.

Derivative standing, however, may allow for precisely the type of legislative-style adjudication that the standing doctrine attempts to prevent: It permits a centralized group to litigate on behalf of an increasingly diffuse body of non-members who may be neither willing to have their claims so pursued nor even aware of the association's actions on their behalf. All forms of representational standing compromise the courts' assurance that the party before them is litigating an injury to a cognizable right in need of redress: The very fact that the party is not representing her own interest causes this doubt. ${ }^{23}$ Derivative standing may compound this concern because the associationtwo steps removed from the third-party right-holder-is even less closely connected to the concrete injury. If the litigating association in derivative standing fails to adequately demonstrate a concrete, par-

20280 F3d at 295.

21 See Lujan $v$ Defenders of Wildlife, 504 US 555, 560 (1992) (calling standing "[o]ne of those landmarks, setting apart the 'Cases' and 'Controversies' that are of the justiciable sort referred to in Article III-'serving to identify those disputes which are appropriately resolved through the judicial process"'), quoting Whitmore v Arkansas, 495 US 149, 155 (1990); Antonin Scalia, The Doctrine of Standing as an Essential Element of the Separation of Powers, 17 Suffolk U L Rev 881 (1983).

22 Warth v Seldin, 422 US 490, 508 (1975), quoting Schlesinger v Reservists to Stop the War, 418 US 208, 221-22 (1974).

23 See Warth, 422 US at 500:

Without such limitations [as the prudential requirement that parties represent their own interests] the court would be called upon to decide abstract questions of wide public significance even though other governmental institutions may be more competent to address the questions and even though judicial intervention may be unnecessary to protect individual rights. 
ticularized injury but rather asserts a mush of grievances widely shared among third-party right-holders, the association will misuse the court to achieve an end better pursued through the legislature. Add into this the general concern that ideologically-minded associations may make use of derivative standing to practice interest group politics in the courts. This new brand of representational standing opens up countless persons' potential claims to litigation by ideologicallyminded associations irrespective of the claim-holders' wishes.

These problems do not arise when associations assert standing on behalf of their own voluntary members: These associations are merely consolidating a number of common claims that members could have brought on their own behalf. ${ }^{24}$ But when associations litigate on behalf of non-members, some fear that a discrete group aided by pooled resources could set an agenda that has effects beyond the group's voluntary membership, and on third parties who are given no opportunity to opt out or affect the course of action that the group takes. The separation-of-powers view of standing posits that policy should not be made through the courts in this way except when the violation of one of the litigants' private rights is at issue. ${ }^{25}$ Adherents of this view would surely demand that associations not be able to bring their own selfmotivated suits on behalf of large, diverse groups of unwitting, potentially unwilling third parties.

\section{Adversarial quality and due process.}

In addition to these separation-of-powers concerns, derivative standing may raise more immediate worries about how those third parties' rights will fare in the face of a derivative standing action. Associations bringing suit on behalf of third parties who hold no stake in the association may pursue those interests only halfheartedly, such that the "concrete adverseness" sought by Article III's case-orcontroversy requirement will be lacking. Every instance of representa-

24 This is one of the primary justifications for associational standing. See text accompanying notes $38-43$.

25 See for example, Lujan, 504 US at 576 (stating that the courts exist to decide individual rights, while "[v]indicating the public interest ... is the function of Congress and the Chief Executive"); Scalia, 17 Suffolk U L Rev at 896 (cited in note 21) (stating that "the doctrine of standing was once meant to restrict judges 'solely, to decide on the rights of individuals"' and should again be so followed), quoting Marbury v Madison, 5 US (1 Cranch) 137, 170 (1803).

26 Indeed, a supporter of the separation-of-powers view of standing may envision derivative standing taken to absurd lengths: What can stop an association of associations from bringing suit on behalf of those secondary associations' members' third parties? One can imagine a pyramid scheme of derivative standing gone wild, in which one head association ultimately brings suit on behalf of all Americans via a circuitous path of associational and third-party standing loosely applied.

27 Baker v Carr, 369 US 186, 204 (1962). 
tional standing allows some slippage between the right-holder's position and the litigant's position. This slippage compromises adversarial litigation because the litigant is unlikely to advocate the right-holder's position as zealously or as knowledgeably as the right-holder would herself. Thus, there is a fear that allowing one representative litigant to represent another who is herself a representative litigant will prove more than the adversarial system can bear.

Second, derivative standing may adversely affect third parties' legal positions. If third parties are either unaware or unwilling tools in a derivative standing case, they may be unable to protect their own due process interests. That is, if derivative standing affects third parties' abilities to bring their own claims, then those third parties' legal rights may be compromised without their awareness or consent; this would be directly contrary to the principle of due process. Furthermore, these third parties may not want their alleged injury to be redressed at all, much less by the means that the association seeks to have judicially enforced. Because the third parties are not members of the association, they will have no capacity to vote against the litigation or withdraw support from the association in the event of a disagreement.

Despite these concerns, derivative standing is not a departure from the standing doctrines that the Court has long recognized and accepted. I argue in Part III that if courts rigorously apply the individual requirements of associational and third-party standing before permitting derivative standing, the concerns about adversarial quality and due process fall away: The protections inherent to those two doctrines likewise protect those involved in derivative standing cases. Additionally, because derivative standing necessarily arises from individualized claims of an association's members' third parties, separation-of-powers concerns do not materialize. An understanding of the theory behind associational and third-party standing is necessary to illustrate why the Court has imposed the restrictions it has on these two forms of standing, as well as how those protections will ensure that derivative standing raises no new concerns while providing added benefits.

\section{LEGAL THEORIES OF ASSOCIATIONAL AND THIRD-PARTY STANDING}

The constitutional root of standing is the Article III Case or Controversy Clause, which limits the jurisdiction of federal courts to "Cases" and "Controversies." tion to mean that a would-be litigant must demonstrate three qualifi- 
cations before a court can hear her claim: injury in fact" to a "concrete, personal interest",; causal connection between the injury and the defendant ${ }^{31}$ and a likelihood that a favorable outcome will redress the injury. ${ }^{32}$ The Court has also noted that, more broadly, the "gist of the question of standing" is whether the parties have alleged "such a personal stake in the outcome of the controversy as to assure that concrete adverseness which sharpens the presentation of issues upon which the court so largely depends." ${ }^{, 33}$ As the "irreducible constitutional minimum of standing," ${ }^{, 34}$ these requirements may not be waived.

The Court has also established prudential requirements of standing, which it has characterized as "part of judicial self-government." ${ }^{35}$ Under the prudential requirements, litigants must bring their own particularized claims rather than the claims of third parties, and the litigant's complaint must be within the "zone of interests" of the statute or constitutional guarantee in question. ${ }^{36}$ These requirements, however, do not rise to the level of standing's constitutional requirements, and courts may waive them as appropriate. ${ }^{37}$ Associational and thirdparty standing are examples of such waivers.

\section{A. Associational Standing}

The Court has held that associations may sue on behalf of their members even in the absence of injury to the association itself. ${ }^{38}$ The justification for this extension of the standing doctrine is based primarily on a functional understanding of associations. In many cases, individuals form associations to represent their interests, both in legislatures and in the courts. ${ }^{39}$ Thus, to deny them standing would defeat a

29 See Lujan v Defenders of Wildlife, 504 US 555, 560 (1992).

30 Allen v Wright, 468 US 737, 756 (1984).

31 See Lujan, 504 US at 560.

32 See id at 561.

33 Bakerv Carr, 369 US 186, 204 (1962).

34 Lujan, 504 US at 560.

35 Id.

36 Valley Forge Christian College v Americans United for Separation of Church and State, Inc, 454 US 464, 474-75 (1982).

37 See, for example, Barrows $v$ Jackson, 346 US 249, 257 (1953) (describing the prudential requirement that parties represent only their own interests as "only a rule of practice" that could be "outweighed by the need to protect ... fundamental rights").

38 See, for example, Warth $v$ Seldin, 422 US 490, 511 (1975), citing National Motor Freight Association v United States, 372 US 246 (1963). Thus, associational standing differs from thirdparty standing because Supreme Court jurisprudence requires no injury to the association analogous to that required for the litigant in third-party standing suits. See, for example, Powers $v$ Ohio, 499 US 400, 411 (1991) (stating that in third-party standing, the litigant must have suffered some injury to him or herself to guarantee a sufficient interest in the litigation).

39 See International Union, UAW v Brock, 477 US 274, 290 (1986) ("[T] he doctrine of associational standing recognizes that the primary reason people join an organization is often to create an effective vehicle for vindicating interests that they share with others."). 
significant part of the reason for associations' existence: "The only practical judicial policy when people pool their capital, their interests, or their activities under a name and form that will identify collective interests, often is to permit the association or corporation in a single case to vindicate the interests of all." ${ }^{, 40}$ Because the developed test for associational standing requires that associations sue only over claims "germane" to the organization's purpose," there is some assurance that suits will be limited to those relating to whatever subject matter the members have joined and supported the association in an attempt to further. ${ }^{42}$ Additionally, the Court has noted practical benefits to allowing associational standing in that "an association suing to vindicate the interests of its members can draw upon a pre-existing reservoir of expertise and capital," thus ensuring a high standard of aggressive advocacy.

Associational standing, however, is not available to every group. In Hunt v Washington State Apple Advertising Commission, the Court articulated the necessary elements for a claim based on associational standing:

[W] have recognized that an association has standing to bring suit on behalf of its members when: (a) its members would otherwise have standing to sue in their own right; (b) the interests it seeks to protect are germane to the organization's purpose; and (c) neither the claim asserted nor the relief requested requires the participation of individual members in the lawsuit. ${ }^{45}$

These requirements collectively ensure that associational standing satisfies the constitutional standing requirements.

The requirement that the members would have standing in their own right is the first step toward satisfying the Article III case-orcontroversy requirement. The Court explained that "the Association must allege that its members, or any one of them, are suffering immediate or threatened injury as a result of the challenged action of the sort that would make out a justiciable case had the members themselves brought suit." ${ }^{46}$ This ensures that the suit will present an active issue as required by the Case or Controversy Clause, rather than a request for an advisory opinion or some other policy matter best left to

40 Id (quotation marks omitted).

41 See Hunt $v$ Washington State Apple Advertising Commission, 432 US 333, 343 (1977).

42 See Brock, 477 US at 290 ("The very forces that cause individuals to band together in an association will thus provide some guarantee that the association will work to promote their interests.").

43 Id at 289.

44432 US 333 (1977).

45 Id at 343.

46 Warth, 422 US at 511. 
the political branches. Further, the requirement that the suit be germane to the association's purposes ensures both that the association has an organizational stake in the litigation ${ }^{47}$ and that the association's capacity for bringing this type of suit is limited to litigation that vindicates its stated purposes. Finally, the requirement that the suit not entail any individual participation by the association's members guarantees that the association is an appropriate litigant and that permitting associational standing serves judicial economy in such a case. ${ }^{48}$ This requirement also limits associational standing to claims for prospective relief. $^{49}$ Under these conditions, associational standing represents sound judicial policy because it allows the consolidation of several claims into one suit, guaranteeing that a litigant has both the institutional capacity and interest to pursue litigation zealously.

While providing these benefits, associational standing does not pose a threat to the due process interests of association members. Since association members would not normally be parties to an associational standing suit, an adverse judgment in the association's case would not preclude subsequent claims by association members under Martin $v$ Wilks. In that case, the Court declared that interested third parties (like association members) were not precluded from bringing subsequent claims if they did not participate in a prior lawsuit. In keeping with the holding of Martin, the Court has suggested that no such preclusive effect should exist for association members.

The Martin holding also protects association members whose interests conflict with the litigation that an association pursues, though such conflicts mitigate the beneficial effects of associational standing. Since associations invoking associational standing need not pass any hurdle of representational adequacy, it is possible for associations to pursue litigation benefiting some of their members at the expense of

47 See United Food and Commercial Workers Union Local 751 v Brown Group, Inc, 517 US 544, 555-56 (1996) ("Hunt's second prong ... raises an assurance that the association's litigators will themselves have a stake in the resolution of the dispute, and thus be in a position to serve as the defendant's natural adversary.").

48 See Nathaniel B. Edmonds, Comment, Associational Standing for Organizations with Internal Conflicts of Interest, $69 \mathrm{U}$ Chi L Rev 351, 356 (2002) ("[T]he individual participation prong ... seeks to ensure that the association will be a better representative than individual members would be in pursuing litigation, thus improving judicial efficiency."); Vivian Weston Lathers, Comment, Associational Third-Party Standing and Federal Jurisdiction under Hunt, 64 Iowa L $\operatorname{Rev} 121,132$ (1978) ("This third provision, then, serves the interests of the courts by requiring all proper parties to be before the court so that all pertinent facts can be presented and individualized justice can be more adequately served.").

49 See Laurence Tribe, 1 American Constitutional Law $\$ 3.20$ at 452 (Foundation 3d ed 2000).

50490 US 755 (1989).

51 See Brock, 477 US at 290 ("Should an association be deficient in [meeting representational adequacy], a judgment won against it might not preclude subsequent claims by the association's members without offending due process principles."). 
others. ${ }^{52}$ Indeed, the Court has stated that a minimum of only one member must be injured before an association can sue on that member's behalf: $:^{33}$ No uniformity of interests among a majority of the membership is necessary. Though Martin protects all association members' due process rights, such internal conflicts of interest diminish the beneficial effects of associational standing for judicial economy because an association pursuing some of its members' interests at the expense of others' is not vindicating the interests of the aggregate of its members and thus combining several related suits into one. ${ }^{55}$ In order to preserve the benefits of associational standing, lower courts have adopted a variety of tests to determine when an association's internal conflicts of interest are too profound to permit effective advocacy by the association on behalf of its members.

\section{B. Third-Party Standing}

Litigants may also represent the interests of third parties in courts under certain conditions. The Court has established three requirements for third-party standing to exist. First, the litigant must have suffered some injury to herself separate from the third party's injury; ${ }^{57}$ this guarantees that the litigant will have a sufficient interest in the litigation to pursue it zealously and satisfies the Article III requirement of injury in fact. ${ }^{58}$ Second, the litigant must have a close relationship with the third party; ${ }^{59}$ this ensures access to relevant information necessary for concrete adverseness. ${ }^{60}$ Finally, the third party must be somehow hindered from bringing suit on her own behalf; ${ }^{61}$

52 One common example of an associational standing case where the association has an internal conflict of interest is trade associations litigating to have statutes providing contract preferences to minority-owned businesses overturned. These statutes benefit minority-owned business members of the association while harming other members. See Edmonds, Comment, $69 \mathrm{U}$ Chi L Rev at 351 (cited in note 48).

53 See Warth, 422 US at 511 ("The Association must allege that its members, or any one of them, are suffering immediate or threatened injury as a result of the challenged action.").

54 See Edmonds, Comment, $69 \mathrm{U}$ Chi L Rev at 360-61 (cited in note 48) ("Many courts have examined the second prong of the Hunt test in determining the appropriate limits of germaneness to an organization, but none has found that unanimity of membership is required, or that any internal conflict of interest automatically forecloses associational standing.").

55 See Donald F. Simone, Note, Associational Standing and Due Process: The Need for an Adequate Representation Scrutiny, 61 B U L Rev 174, 176 (1981) (stating that the Court rationalizes associational standing because an association is considered to be the aggregate of its members).

56 See Edmonds, Comment, 69 U Chi L Rev at 351 (cited in note 48).

57 See Powers, 499 US at 411.

58 See notes 29-30 and accompanying text.

59 See Singleton $v$ Wulff, 428 US 106, 115 (1976).

60 See id ("[T]he relationship between the litigant and the third party may be such that the former is fully, or very nearly, as effective a proponent of the right as the latter.").

61 See id at $115-16$. 
this requirement ameliorates the concern that the third party may not wish to assert her rights or that those rights are not truly at issue. These conditions are strictly applied because "[o]rdinarily, one may not claim standing ... to vindicate the constitutional rights of some third party." ${ }^{, 63}$ This is based on the understanding that the third party is likely to be a better proponent of her own rights than the would-be litigant. As a result, courts exercise caution in permitting third-party standing. ${ }^{64}$

Even in light of this caution, however, the Court has recognized that third-party standing is occasionally appropriate:

If the enjoyment of the right is inextricably bound up with the activity the litigant wishes to pursue, the court at least can be sure that its construction of the right is not unnecessary in the sense that the right's enjoyment will be unaffected by the outcome of the suit. Furthermore, the relationship between the litigant and the third party may be such that the former is fully, or very nearly, as effective a proponent of the right as the latter.

Given the strict application of these three conditions, third-party standing allows for a reasonable expansion of the opportunity to litigate without overly compromising separation of powers or permitting unchecked litigation on behalf of unwilling or unwitting third parties.

An early example of the allowance of third-party standing is Barrows $v$ Jackson, ${ }^{66}$ in which the Court permitted a white homeowner, defending a breach of contract claim for allowing non-whites to occupy her home despite a racial covenant, to argue an affirmative defense based on the constitutional rights of potential black buyers. Because the unnamed black buyers were not parties to the contract action, they could not argue their own constitutional rights. However, the white homeowner faced injury based on the violation of their constitutional rights because she would be compelled to pay damages if the breach of contract action were upheld. The Court explained: "[W]e believe the reasons which underlie our rule denying standing to raise another's rights, which is only a rule of practice, are outweighed by the need to protect the fundamental rights which would be denied by permitting the damages action to be maintained." ${ }^{167}$ Thus, third-party standing was allowed for the white defendant because the interests of

62 See id ("If there is some genuine obstacle to [the third party's assertion of his own rights], however, the third party's absence from court loses its tendency to suggest that his right is not truly at stake, or truly important to him.").

63 Barrows, 346 US at 255.

64 See Singleton, 428 US at 113-14.

65 Id at $114-15$.

66346 US 249 (1953).

67 Id at 257. 
justice required the invalidation of the racial covenant, but the Court could invalidate it only by relying on the constitutional rights of the potential black buyers. Article III was satisfied because the defendant faced injury in her own right, thus guaranteeing a true case or controversy. ${ }^{68}$ In addition, the prudential concern that the unnamed black home buyers would be compelled to have rights protected that they might not desire having protected was mitigated because it was clear that regardless of their wishes, the only way their rights could be protected was for the homeowner to have standing on their behalf. ${ }^{69}$

While the requirement that the right-holder be hindered from bringing suit on her own behalf is intended to ensure that litigants argue third parties' claims only when such a scenario serves the interests of justice, interpretations of this requirement have varied. In an early case permitting third-party standing, the Court allowed standing because the hindrance was procedurally insurmountable. In NAACP v Patterson, ${ }^{70}$ the Court allowed the NAACP to argue its members' rights to freedom of association in refusing to give their membership list to the state of Alabama because forcing the members to litigate this right on their own would be a denial of the very right in question. The Court stated, "To require that [the right to freedom of association] be claimed by the members themselves would result in nullification of the right at the very moment of its assertion." Barrows involved a similar situation of procedurally insurmountable hindrance, making third-party standing appropriate."

But in subsequent cases, courts have recognized third-party standing where the hindrance is not insurmountable. In more recent cases, courts have allowed third-party standing where the sole hindrance to the third party is a limited incentive to litigate on her own behalf. For example, in Powers $v$ Ohio ${ }^{73}$ the Court held that an excluded juror's limited incentive to bring a suit based on racial discrimination in jury selection satisfied the hindrance requirement for a criminal defendant to obtain third-party standing on the juror's behalf. In a different case, Justice Brennan expressed concern that the Court "only rarely interpose[s] a bar to third-party standing." The evolution

\footnotetext{
68 See id at 255-56 (finding respondent satisfied injury requirement because she might have to pay damages, which would "constitute a direct, pocketbook injury").

69 See id at 259 ("[R]espondent is the only effective adversary of the unworthy covenant.").

70357 US 449 (1958).

71 Id at 459.

72 See 346 US at 259.

73499 US 400, 415 (1991).

74 Valley Forge Christian College, 454 US at 493 n 4 (Brennan dissenting).
} 
of the lowering of the hindrance standard has likewise been cause for concern among legal scholars.

As more recent Court decisions allowing third-party standing have diminished the need to show an insurmountable hindrance, it becomes more difficult to see a consistent framework that describes the series of third-party standing decisions. One possibility is that thirdparty standing cases are, in most instances, actually a form of firstparty standing. Under this conception, the defendant in Barrows, for example, was effectively attempting to vindicate her own right to sell her house to black buyers. The criminal defendant in Powers was asserting his own right to a trial with a racially integrated jury pool. In other words, these two litigants sought to vindicate their own personal rights to interact with the third parties in question without being subject to regulations that violated the third parties' constitutional rights and made the interaction impossible. Thus, these litigants sought to assert their own "interactive liberty":

[A] litigant asserts his own rights (not those of a third person) when he seeks to void restrictions that directly impair his freedom to interact with a third person who himself could not legally be prevented from engaging in the interaction... The litigant is asserting a substantive due process right to interact with a third party right holder free from unjustifiable governmental interference. $^{70}$

\section{DERIVATIVE STANDING AS A VALID AND BENEFICIAL EXTENSION OF STANDING DOCTRINE}

As discussed in Part I.B, there is a persistent idea that derivative standing is fundamentally different from either associational or thirdparty standing because derivative standing involves two steps between the right-holder and the litigant, while associational and third-party standing each involve only one. In actuality, however, the extra step poses no constitutional or practical problem, and derivative standing is therefore a valid extension of standing doctrine. By adhering to the requirements the Court has established for those two doctrines individually, courts can ensure that no additional problems arise from their combination.

75 See, for example, Henry P. Monaghan, Third Party Standing, 84 Colum L Rev 277, 278 (1984) (expressing concern that third-party standing had been reduced to "discretionary rules of judicial practice"); David P. Currie, Misunderstanding Standing, 1981 S Ct Rev 41. These criticisms correctly suggest that, as courts lower the hindrance requirement to allow more litigants to bring third-party suits, the concern that those third parties will have their interests litigated contrary to their wishes increases. See text accompanying notes 125-26.

76 Monaghan, 84 Colum L Rev at 282, 299 (cited in note 75). 
There are two prongs to the test for derivative standing: An association may assert derivative standing only when it can demonstrate 1) that it has associational standing on behalf of its members; and 2) that its members have third-party standing on behalf of some third-party right-holders." More specifically, the litigating association must assert its own associational standing by demonstrating the following three factors: its members would have standing in their own right, the subject of the litigation is germane to the association's purpose, and individual participation by the association's members will not be necessary for successful litigation. ${ }^{78}$ It must separately assert that its members would have third-party standing in their own right to bring the third-party right-holders' claims. To assert the association members' third-party standing, the litigating association must show the following three factors: the members have suffered injury to themselves, the members have a close relationship with the right-holders, and the right-holders are hindered from bringing their own claims. ${ }^{79}$ Derivative standing fails if any of these six factors is not present. If standing law is in fact properly applied such that all six of these factors are present, courts can ensure that an association will represent its members' third parties with the same adversarial zeal with which it would represent its own members or with which an individual litigant would represent a third party. Further, such litigation will not affect the rights of the members' third parties, nor will the association's representation be inadequate in protecting those rights. Finally, derivative standing does not allow groups to gain inappropriate access to courts.

\section{A. Adversarial Quality}

The Article III case-or-controversy requirement and the Court's prudential standing requirements ${ }^{80}$ recognize that in an adversarial system, courts are in the best position to decide parties' rights when both parties represent their interests zealously. Such zealous advocacy promotes concrete adverseness by indicating the full extent of support that exists for each position and ensuring that the dispute presents an active issue rather than a broad question of policy or source for an advisory opinion. Any form of representational standing potentially compromises this concrete adverseness because the party whose right is being advocated (and who generally has the most at stake) is not

77 This two-pronged test results from the definition of derivative standing as the combination of associational and third-party standing.

78 These are the standard requirements for associational standing. See Hunt, 432 US at 343.

79 These are the standard requirements for third-party standing. See Powers, 499 US at 411.

80 For a discussion of the constitutional and prudential standing requirements, see text accompanying notes $28-37$. 
before the court; ${ }^{81}$ derivative standing, with its two steps of removal between litigant and right-holder, raises this concern doubly. However, to assert derivative standing, a litigating association will need to show that its members have third-party standing to bring the claims at issue. The requirements for third-party standing are sufficient to ensure that an association's members-and by turn the association-have the requisite interest in a derivative-standing lawsuit to guarantee concrete adverseness. To achieve third-party standing, the members of an association must themselves suffer injury ${ }^{82}$ and must be involved in a significant relationship with the third parties, ${ }^{83}$ these requirements guarantee an interest in the outcome and access to necessary information. The presence of these factors will ensure that derivative standing satisfies both the constitutional and prudential requirements for standing.

1. Concrete adverseness and the constitutional requirements in derivative standing.

The Court has interpreted Article III to require that litigants demonstrate a concrete injury to themselves in order to achieve standing. This requirement serves in large part to ensure concrete adverseness in litigation because litigants who have suffered an injury are most likely to provide zealous advocacy. Because this is a constitutional requirement, any extension of standing doctrine must satisfy it; it cannot be waived. ${ }^{85}$ The Court has held that third-party standing satisfies the injury-in-fact requirement because a third-party litigant must demonstrate an injury to herself in addition to the right-holder's injury. The injury to the litigant ensures that she will maintain an interest in the litigation and advocate zealously on the third party's behalf. Associational standing is somewhat different because the litigating association need not be injured in its own right. Because its primary

81 Representational standing, by definition, occurs when the litigant represents the interests of someone not before the court.

82 See Singleton $v$ Wulff, 428 US 106, 114-15 (1976) (noting that a sufficient congruence of interests exists when the activity that the litigant wishes to pursue can occur only if the thirdparty right is vindicated).

83 See Powers, 499 US at 411.

84 See Lujan $v$ Defenders of Wildlife, 504 US 555, 560 (1992).

85 See text accompanying note 34.

86 See Powers, 499 US at 411. See also Robert Allen Sedler, The Assertion of Constitutional Jus Tertii: A Substantive Approach, 70 Cal L Rev 1308, 1318 (1982) (arguing that third-party standing satisfies Article III because where "plaintiffs and defendants assert an injury to themselves, [they] clearly fulfill[] standing requirements").

87 See Powers, 499 US at 411 (noting that for third-party standing, "[ $t$ ]he litigant must have suffered an 'injury in fact,' thus giving him or her a 'sufficiently concrete interest' in the outcome of the issue in dispute"), quoting Singleton, 428 US at 112. 
purpose is to act as a representative for its members, ${ }^{88}$ an association has no independent existence other than as a coalition of its members; thus, the Court has held that an injury to an association's members is equivalent to an injury to the association.

Derivative standing likewise satisfies the Article III injury-in-fact requirement. By definition, derivative standing arises only when an association's members satisfy third-party standing requirements in their own right. ${ }^{90}$ In order to have third-party standing, association members must necessarily have suffered injury to themselves. ${ }^{91}$ The litigating association then brings suit on the basis of those injuries to its members just as it would in the context of associational standing. According to associational standing doctrine, when an association brings suit based on its members' injuries, it satisfies the injury-in-fact requirement. ${ }^{22}$ Thus, in this sense, derivative standing presents no more of an extension of standing doctrine than either third-party or associational standing; instead, derivative standing is fully consistent with both of those well-established extensions. In a derivative standing suit, the members-having suffered injury to themselves-have every incentive to ensure that the association maintains an interest in the litigation and advocates zealously on their behalf, just as they do in associational standing suits.

While the association members in a derivative standing suit have suffered injury to themselves, the association asserts not the members' rights but the rights of those members' third parties. ${ }^{93}$ This is what dis-

88 See, for example, Warth v Seldin, 422 US 490, 511 (1975) ("Even in the absence of injury to itself, an association may have standing solely as the representative of its members."), citing National Motor Freight Traffic Association, Inc v United States, 372 US 246, 247 (1963).

89 See Warth, 422 US at 511 ("[T]he Association must allege that its members, or any one of them, are suffering immediate or threatened injury as a result of the challenged action of the sort that would make out a justiciable case had the members themselves brought suit.").

90 Derivative standing arises when an association asserts associational standing to bring claims that the association's members would have third-party standing to bring in their own right. For example, in Pennsylvania Psychiatric Society, the psychiatrists' trade association, PPS, could assert derivative standing because its members, the psychiatrists, had third-party standing in their own right to bring their patients' claims. See 280 F3d 278. Had the psychiatrists not had third-party standing to bring their patients' claims, derivative standing would not have been possible for the association.

91 Such injury is a prerequisite of third-party standing. See note 86 and accompanying text.

92 See note 89 and accompanying text.

93 The facts of Pennsylvania Psychiatric Society, 280 F3d 278, provide a helpful illustration of this concept. The right asserted in that case was the patients' right to authorization for psychiatric treatment under their contracts with HMOs. This right belonged to the patients, not their psychiatrists. However, the psychiatrists were harmed by losing business when patients were wrongfully denied authorization for treatment. Thus, the psychiatrists-and, in turn, the psychiatrists' trade association, PPS - had sufficient interest in the litigation to advocate zealously for enforcement of the patients' rights to treatment authorization. The injury to the psychiatrists in the form of loss of business thus satisfied the injury-in-fact requirement, even though the right in question belonged to the patients rather than the psychiatrists. 
tinguishes derivative standing from associational standing. However, the Article III standing requirement is not concerned with whose rights are being asserted. Rather, that inquiry is part of the prudential test for standing. And it is the prudential component of standing to which the Court has seen fit to make exceptions as justice requires. These "judicially self-imposed limits on the exercise of federal jurisdiction" ${ }^{\text {"ब4 }}$ may be - and frequently have been - waived or modified to meet the needs of a given case or category of cases. ${ }^{95}$ Thus, since there is nothing like the "irreducible constitutional minimum" of Article III to tie down the prudential component of standing, derivative standing should be permissible to the extent that it satisfies the same prudential or equitable concerns as other exceptions to the prudential rules of standing.

2. Concrete adverseness and the prudential requirements of standing.

Under the prudential requirements of standing, a litigant may normally pursue only her own interests." However, the Court has waived this prudential rule where the requirements for associational and third-party standing are met. In those two situations, the prudential rule's "underlying justifications are absent" ments for associational and third-party standing ensure concrete adverseness even though the litigant is representing interests other than her own. Extending this exception to allow derivative standing is also consistent with the prudential rule's underlying justifications: Because derivative standing arises only when all six requirements of associational and third-party standing together are met, concrete adverseness is preserved even though the litigating association is not arguing its own or its members' claims.

To achieve derivative standing, the association must show that its members have third-party standing in their own right. To have thirdparty standing, the members must be involved in some "close relation-

94 Allen $v$ Wright, 468 US 737, 751 (1984).

95 See, for example, Barrows, 346 US at 257 ("Under the peculiar circumstances of this case, we believe the reasons which underlie our rule denying standing to raise another's rights, which is only a rule of practice, are outweighed by the need to protect the fundamental rights which would be denied by permitting the damages action to be maintained.") (emphasis added).

96 Lujan, 504 US at 560.

97 See, for example, Barrows, 346 US at 255 ("Ordinarily, one may not claim standing ... to vindicate the ... rights of some third party.")

98 Singleton, 428 US at 114 (referring to third-party standing). For a similar remark applying to associational standing, see Joint Anti-Fascist Refugee Committee v McGrath, 341 US 123, 187 (1951) (Jackson concurring) (calling associational standing "the only practical judicial policy"). 
ship" with the right-holders. ${ }^{99}$ The close relationship requirement of third-party standing ensures both that the litigant's and third party's interests will be aligned and that the litigant will have access to relevant information while pursuing the third party's claim. Past examples of satisfactory relationships in third-party standing cases include vendor/vendee, ${ }^{100}$ doctor/patient, ${ }^{101}$ and defendant/juror. ${ }^{102}$

The crucial characteristic of these "close" relationships is that the litigant benefits from victory in the suit irrespective of any benefits to the third-party right-holder. ${ }^{103}$ That is, the Court has found a close relationship between the third-party litigant and the right-holder in situations where the two shared a relationship that was burdened so as to injure both parties; the litigant then, seeking to regain her own interactive liberty, ${ }^{104}$ brought suit based on the third party's right. In other words, "a litigant asserts his own rights (not those of a third person) when he seeks to void restrictions that directly impair his freedom to interact with a third person who himself could not legally be prevented from engaging in the interaction." ${ }^{105}$ For example, the house owner in Barrows who wins a suit vindicating the equal protection right of black buyers to buy her house wins for herself the ability to sell the house to black buyers. ${ }^{106}$ The Court has permitted third-party standing in these cases precisely because it serves the interests of both the litigant and the third-party right-holder. ${ }^{107}$

In the context of derivative standing, it is the association members who have third-party standing to bring the right-holders' claims. Thus, according to the above formulation, the members would have an interest in pursuing the suit irrespective of whatever benefit their victory would bring to the third-party right-holders. In other words, the members would have an independent interest in securing a favorable outcome.

99 See Powers, 499 US at 411.

100 See Craig v Boren, 429 US 190, 192-93 (1976).

101 See Singleton, 428 US at 117.

102 See Powers, 499 US at 415.

103 Because the third-party right being asserted does not necessarily match up with the litigant's injury, simply vindicating the right would not necessarily secure redress for the plaintiff's injury. However, by requiring a close relationship between the litigant and the third party, it becomes more likely that the third party's right and the litigant's injury will map on to each other. Hence, these two requirements work synergistically to ensure concrete adverseness.

104 See text accompanying note 76.

105 Monaghan, 84 Colum L Rev at 299 (cited in note 75).

106 See generally Barrows, 346 US 249. See also text accompanying note 76.

107 This does not answer the question of whether, in all cases, the third-party right-holder is necessarily desirous of having her right vindicated. It is certainly plausible that in some instances, a right-holder might prefer to see her right not vindicated. The hindrance requirement of thirdparty standing seeks to ameliorate this concern, and I will discuss the issue further in the following section. See text accompanying notes 124-27. 
Derivative standing, however, adds the additional step of associational standing: The association, not its members, litigates the claims. But if the members in fact have an interest in the litigation apart from the third-party right-holders - that is, if the members have their own independent interest - then derivative standing is prudentially no different from associational standing. ${ }^{108}$ It is simply an association representing its members' independent interests. This answers the concern that two steps of removal between the litigant and the right-holder will create too much slippage to ensure concrete adverseness. ${ }^{109}$ On the contrary, the association will have just as much incentive to advocate zealously for its members' independent interests in a derivative standing suit as it would in an associational standing suit. In both cases, the association represents its members' independent interests. Similarly, in both cases, having the association represent the aggregate of its members' interests can provide significant economies of scale and is thus not merely prudentially sound, but also prudentially advisable.

\section{B. Due Process and the Interests of the Members' Third Parties}

Apart from any concerns about derivative standing and the preservation of concrete adverseness, there may be concern that allowing associations to sue on behalf of their members' third parties rather than the members themselves will impede due process because the association may be an inadequate representative of the interests of nonmembers with no stake in the association. But derivative standing poses no greater concern than do associational standing and thirdparty standing individually. Furthermore, derivative standing offers benefits of increased access to justice. The protections of associational standing serve to ensure that the third parties will not lose due process rights thanks to litigation undertaken based on derivative standing;

108 The interests that the members would seek to vindicate must also be germane to the association's purpose in order to invoke associational standing and the resulting derivative standing. See Pennsylvania Psychiatric Society, 280 F3d at 291, quoting Hunt, 432 US at 343:

A third-party claim must also meet the requirement[] that "the interests it seeks to protect are germane to the organization's purpose." ... Th[is] factor[] inform[s] the analysis whether an association stands in the correct relationship to a claim to allow it to assert that claim on behalf of others.

The germaneness of the members' interest to the association's purpose further serves to ensure that the association will pursue the claim with requisite zeal.

109 See Part I.B.2.

110 One commentator noted that "[b]esides financial resources, organizations often have specialized expertise and research resources relating to the subject matter of the lawsuit that individualized plaintiffs lack." Dale Gronemeier, Comment, From Net to Sword: Organizational Representatives Litigating Their Members' Claims, 1974 U Ill L F 663, 669. According to the Court, "[t]hese resources can assist both courts and plaintiffs." International Union, UAW v Brock, 477 US 274, 289 (1986). 
the protections of both associational and third-party standing serve to ensure that those third parties will not be forced into acting as litigants or pursuing claims that they prefer not to pursue.

\section{Due process effects of derivative standing.}

It is a fundamental principle of due process that "one is not bound by a judgment in personam in a litigation in which he is not designated as a party or to which he has not been made a party by service of process." "111 For this reason, an adverse outcome in an associational standing suit does not preclude subsequent claims of the association members. ${ }^{112}$ Members are not parties to litigation in an associational standing case, but rather interested third parties. ${ }^{113}$ It is settled law that the claims of interested third parties may not be precluded by prior adverse judgments. ${ }^{114}$ To the extent that any courts have allowed such claim preclusion against association members, their decisions conflict with the holding of Martin $v$ Wilks. ${ }^{115}$

This means that association members cannot face preclusion because of the association's prior litigation even though association members are voluntarily involved in the association and likely have some impact on the association's decision whether and how to undertake the litigation. The members' third parties (that is, the psychiatrists' patients in Pennsylvania Psychiatric Society), however, have not joined the association and have no say in its course of action; they are even less "interested" than the members themselves. If the members cannot face preclusion, then it follows that their third parties cannot either. ${ }^{116}$ This point is made particularly clear when one considers that

111 Hansberry $v$ Lee, 311 US 32, 40 (1940) (holding that petitioners were not bound by a prior adjudication of the validity of a restrictive covenant because they were not in privity with any party from the prior adjudication).

112 For the purposes of this discussion, I use "preclusion" to refer to both issue and claim preclusion. The analysis applies to them equally. Also, note that in the case of representational standing, an "adverse" outcome from the perspective of the right-holder whose interests are litigated by another could include either a suit in which the litigant fails or one in which the litigant is victorious, but the right-holder opposed the litigant's position.

113 It is instructive to compare an associational standing suit to a class action suit. In a class action suit, the representative plaintiff must demonstrate rigorous adequacy, typicality, and commonality qualifications. See FRCP 23. In the absence of these qualifications, the class will not be certified, and judgments for or against the representative plaintiff will not extend to the other class members. The analogous qualifications required for associational standing do not rise to the level of the class action requirements. See Brock, 477 US at 288-90.

114 See Martin, 490 US at 762.

115490 US at 762. For a discussion of this issue written before the Martin decision and a recommendation that courts undertake more stringent examinations of the adequacy of associations as representatives because of the danger of such subsequent claim preclusions, see Simone, Note, $61 \mathrm{~B} \mathrm{U} \mathrm{L} \mathrm{Rev} \mathrm{at} 184-87$ (cited in note 55).

116 Like the association members, the members' third parties would constitute "interested third parties" under Martin. 
associational standing is permitted even when there is a minor internal conflict of interest among the association's members or when less than a majority of the members explicitly support the litigation. ${ }^{117} \mathrm{Be}-$ cause the members' individual claims are not precluded upon the association's failure in litigation, due process considerations raise little concern. And irrespective of any minor internal conflicts of interest, the benefits of associational standing to judicial efficiency remain: Claims for prospective relief shared by a number of association members are litigated in one case by one party that enjoys a "reservoir of expertise and capital."118

Internal conflicts of interest should not be of greater concern for derivative standing than for associational standing. Functionally speaking, conflicts of interest among members' third parties may be less likely to prevent the association from going forward in litigation than conflicts of interest within the association's membership because the third parties are not entitled to a say in the association's decision whether to undertake litigation. However, associations asserting derivative standing will have to demonstrate that their members have third-party standing to bring the third-party right-holders' claims. The protections afforded those third-party right-holders by the third-party standing requirements will ensure a degree of unanimity equal to that of the members themselves.

The association members will rightly have third-party standing only when they are involved in close relationships with the third parties and when some invalid condition on those relationships injures both the association members and the third parties. ${ }^{119}$ The legal theory behind these conditions is that through their application, the litigant and the third-party right-holder's interests are both served when the litigant is victorious; third-party standing is prudentially sound because its close relationship requirement serves to ensure that the litigant's and the right-holder's interests are well aligned. ${ }^{120}$ In the context of derivative standing, the association members will have third-party standing only if their interests are well aligned with the third-party

117 See, for example, National Association of College Bookstores, Inc v Cambridge University Press, 990 F Supp 245, 251 (SD NY 1997) ("[M]inor conflicts involving a small minority of an association's membership [are] immaterial to standing analysis."). See also note 56 and accompanying text. For a more thorough discussion of internal conflict in associational standing, see generally Edmonds, Comment, 69 U Chi L Rev 351 (cited in note 48).

118 Brock, 477 US at 289. See also National Association of College Bookstores, 990 F Supp at 251 (stating that denying associational standing in all cases of minor internal conflict of interest "would clearly be inimical to the goal of judicial efficiency: It is precisely in cases where large organizations are present that the greatest benefits are to be reaped by collective adjudication").

119 See Powers, 499 US at 411; Monaghan, 84 Colum L Rev at 297 (cited in note 75). See also text accompanying note 76 .

120 See text accompanying notes 99-109. 
right-holders. Because the members' interests must align with the third-party right-holders' interests, the third-party right-holders will face a conflict of interest in precisely the same measure as the members themselves. Therefore, the analysis of internal conflicts of interest ought to be the same as is normally undertaken in associational standing.

The above analysis also answers the concern that an association may not have the members' third parties' best interests in mind when it pursues litigation. The requirements for third-party standing make it such that even if the association strives solely for the benefit of its own members, a successful outcome to its litigation will likewise inure to the benefit of the third-party right-holders since the members' and third-party right-holders' interests will be aligned. Because the legal theory of third-party standing suggests that the practice is prudential only when its allowance will further the cause of both the litigant and the third party, any litigation that benefits the association members must necessarily benefit their third parties.

\section{Collateral effects on members' third parties.}

One potential problem of derivative standing is that it allows an association to achieve its own ends by using the claims of third-party right-holders who do not wish to have their rights litigated. However, the concern that the third-party right-holders will become unwitting and unwilling quasi-plaintiffs is no greater than the related concern in standard third-party standing. The Court has recognized that ordinarily, "the courts should not adjudicate such rights [of third parties] unnecessarily, and it may be that in fact the holders of those rights either do not wish to assert them, or will be able to enjoy them regardless of whether the in-court litigant is successful or not." ${ }^{121}$ However, this has not prevented the court from accepting the practice of third-party standing under those conditions spelled out above. ${ }^{122}$ One answer to this issue is that the requirement of a close relationship ensures that the court adjudicates the third party's right only when such an adjudication is necessary for the litigant to engage in that relationship.

The requirement that the third party be somehow hindered from bringing her own claim, though, is the primary answer to this con-

\footnotetext{
121 Singleton, 428 US at 113-14.

122 See text accompanying notes 57-62.

123 See Singleton, 428 US at 114-15:
}

If the enjoyment of the right is inextricably bound up with the activity the litigant wishes to pursue, the court at least can be sure that its construction of the right is not unnecessary in the sense that the right's enjoyment will be unaffected by the outcome of the suit. 
cern. ${ }^{124}$ This answer applies equally to derivative standing. Because the association members must satisfy the requirements for third-party standing before derivative standing can exist, it is a necessary condition that the members' third parties must be somehow hindered from bringing suit in their own right. This minimizes the chance that the third-party right-holders' collective silence reflects an aversion to their rights' vindication.

This becomes problematic, however, if the hindrance requirement is blithely passed over in a court's analysis of the requisite conditions for derivative standing. As courts and commentators have noted, the hindrance requirement for standard third-party standing has declined from being a requirement of insurmountable hindrance ${ }^{125}$ to one of limited incentive. ${ }^{126}$ There seems to be little theoretical principle behind the hindrance requirement since its form has been so malleable. But this condition is particularly important in the case of derivative standing because the group of third parties is sufficiently large and diffuse that there is a real danger that some third parties may have rights litigated contrary to their wishes. Fortunately, the conflict of interest analysis discussed above also serves to protect those third parties who would oppose the association's litigation to some extent, so even in light of the currently unsettled jurisprudence in this area, the unwelcome effects of derivative standing will be minimized.

On its flip side, the hindrance requirement serves to illustrate the significant benefits of derivative standing. The third parties in question in derivative standing are, by virtue of the third-party standing restrictions, somehow hindered from bringing suit on their own behalf. By permitting derivative standing, those third parties' rights will be litigated by a body (the association) with a "reservoir of expertise and capital." ${ }^{127}$ Furthermore, associational standing serves judicial economy by bringing together the claims of a group of association members to be litigated by one advocate. Third-party standing serves the interests of justice by allowing the litigation of a right that would otherwise not be vindicated. Combined into derivative standing, these two doctrines mean that the members' third parties will see their rights litigated in court by a particularly efficient and competent advocate.

124 See id at 116 ("If there is some genuine obstacle to such assertion, however, the third party's absence from court loses its tendency to suggest that his right is not truly at stake, or truly important to him, and the party who is in court becomes by default the right's best available proponent.").

125 See Patterson, 357 US at 459 (allowing third-party standing where a requirement that the right-holders litigate on their own behalf was tantamount to denying the right altogether).

126 See Powers, 499 US at 414-15 (holding that excluded juror's limited incentive to bring discrimination suit satisfied obstacle requirement for criminal defendant to merit third-party standing).

127 Brock, 477 US at 289. 


\section{Derivative Standing and Separation of Powers}

Finally, some have argued that any standing doctrine that allows greater access to federal courts should be treated with suspicion, since standing is a fundamental principle of separation of powers, keeping the courts limited to their proper role. ${ }^{128}$ Under this argument, extensions of representational standing are particularly worrisome because when the party before the court is not the right-holder, the courts are less certain that they are not deciding questions (and potentially imposing their own views on the other branches) unnecessarily. ${ }^{129}$ The separation-of-powers argument might be particularly applicable in the case of derivative standing because derivative standing permits an association to bring claims on behalf of a diffuse group of people who likely suffer injuries too small to merit litigation on their own behalf. An association may attempt to achieve sweeping policy changes by uniting the minimal claims of third-party right-holders-who would not likely pursue the claims in their own right and may even oppose the association's litigation-and forcing courts to pick a side. Such a scenario may "require a court to rule on important ... issues in the abstract [and] create the potential for abuse of the judicial process ... and open the Judiciary to an arguable charge of providing 'government by injunction." 130

Derivative standing, however, does not violate the principle of separation of powers because the litigating association's claim arises from the concrete injuries of the third-party right-holders. ${ }^{131}$ Though the association is uniquely removed from the right-holder in derivative standing, that removal does not render the right-holder's injury any less concrete. And as long as there is a concrete injury before the court (even if the right-holder who was concretely injured is not the litigant), the court will be able to determine the bounds of its judicial authority and obligation. "[T]he discrete factual context within which the concrete injury occurred or is threatened insures the framing of

\footnotetext{
128 See generally Scalia, 17 Suffolk U L Rev at 881 (cited in note 21).

129 See Warth, 422 US at 500:
}

Without such limitations [as the prudential requirement that parties represent their own interests] the court would be called upon to decide abstract questions of wide public significance even though other governmental institutions may be more competent to address the questions and even though judicial intervention may be unnecessary to protect individual rights.

130 Schlesinger v Reservists Committee to Stop the War, 418 US 208, 222 (1974).

131 For an association to assert derivative standing, it must be able to demonstrate that its members have third-party standing to bring the third-party right-holders' claims. If the thirdparty right-holders have no colorable claims (in other words, if they have suffered no concrete injury), then there are no claims that the association members have third-party standing to bring, and derivative standing necessarily fails. 
relief no broader than required by the precise facts to which the court's ruling would be applied.", ${ }^{132}$

The fact that the right-holders' concrete injuries are small and widely shared also poses no problem for separation of powers. The Court has determined that "generalized grievances" - namely abstract harms that are widely shared - are not appropriate for judicial review but rather should be reserved for the political process. ${ }^{133}$ But the Court has distinguished generalized grievances from widely shared concrete injuries: "Often the fact that an interest is abstract and the fact that it is widely shared go hand in hand. But their association is not invariable, and where a harm is concrete, though widely shared, the Court has found 'injury in fact.","134 Since derivative standing applies only where the third-party right-holders have suffered concrete injury, ${ }^{135}$ the fact that their injuries are widely shared does not conflict with the principle of separation of powers.

Even though the third-party right-holders have suffered concrete injury, there may remain a concern that the litigating association's two steps of removal from those right-holders adversely affects the association's ability to define those concrete injuries before the court. However, as discussed in Part III.A, the requirements of associational and third-party standing - which the association must demonstrate in order to assert derivative standing - assuage this concern. The association must show that its members have third-party standing to bring the right-holders' claims. This in turn requires that the members have a close relationship with the third-party right-holders, which ensures that the members have access to necessary information and an alignment of interests with the right-holders. ${ }^{136}$ The association must also show that it has associational standing on behalf of its members. This in turn requires that the claims in question not be of a type where individual participation by the members (or, in derivative standing, by the third-party right-holders) is necessary. ${ }^{137}$ Thus, no injury where specific, personal information is necessary will come under the rubric of derivative standing, and the association members will have a close relationship with the third-party right-holders to obtain whatever information is necessary.

132 Schlesinger, 418 US at 222.

133 See, for example, Federal Election Commission v Akins, 524 US 11, 23 (1998) ("[W]here large numbers of Americans suffer alike, the political process, rather than the judicial process, may provide the more appropriate remedy for a widely shared grievance.").

134 Id at 24.

135 See note 131.

136 See notes 99-107 and accompanying text.

137 See Hunt, 432 US at 343. 
Furthermore, the same prudential reasons that have made us accept associational and third-party standing individually are at work here. While an argument can be made that some of the third-party right-holders might not desire to see their claims vindicated, an argument at least equally powerful can be made to the opposite effect: If derivative standing provides an avenue into the courts for people with justiciable claims that will otherwise not be brought, then it promotes the operation of justice. ${ }^{138}$ Those third-party right-holders who believe that a court wrongly decided derivative standing litigation in favor of the association are not subsequently precluded from bringing their own claims.

Even if permitting derivative standing means opening the courts to claims they might not otherwise hear, requiring the rigorous tests of third-party and associational standing will guarantee that those claims are zealously advocated and that the adjudication satisfies due process. Furthermore, the prerequisites to achieving derivative standing will ensure that organizations will not invent a derivative standing case simply to achieve their own policy objectives. Beyond the necessity of a concrete injury to the third-party right-holders, the association must demonstrate that it satisfies the requirements for associational standing to bring its members' claims and that its members satisfy the requirements for third-party standing to bring the claims of the third-party right-holders. ${ }^{139}$ Even if derivative standing could theoretically expand to encompass the claims of millions in a law school hypothetical, such an outcome is inconceivable in the real world. The substantial burden of establishing the presence of all factors required for derivative standing would preclude such an outcome. The federal courts should not be closed to this type of claim merely for the sake of limiting standing and thereby access to the courts: Where an extension of the standing doctrine serves to allow the courts to reach concrete injuries, it falls well within the bounds of the traditional judicial role.

\section{CONCLUSION}

Derivative standing creates no greater perils than does either associational or third-party standing individually, but it promises additional benefits. The protections that courts have built into associational and third-party standing to ensure constitutionality and prudence work to ensure the same in derivative standing. Furthermore,

138 A broad reading of Marbury $v$ Madison supports this interpretation: "The very essence of civil liberty certainly consists in the right of every individual to claim the protection of the laws, whenever he receives an injury." 5 US (1 Cranch) 137, 163 (1803). $77-79$.

139 For a discussion of what these demonstrations entail, see text accompanying notes 
the benefits of derivative standing accede to courts in the form of judicial economy and to people somehow barred from pursuing their own claims in the form of improved access to justice. Courts should allow the practice of derivative standing under the recommended conditions. 


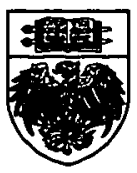

